\title{
ANALISIS FAKTOR-FAKTOR YANG MEMPENGARUHI MINAT MAHASISWA STEI SEBI JURUSAN AKUNTANSI SYARIAH TERHADAP PROFESI AKUNTAN PUBLIK
}

\author{
Niswatul Mahmudah \\ Program Studi Akuntansi Syariah \\ Sekolah Tinggi Ekonomi Islam SEBI \\ Email: anisaddanuri@yahoo.com
}

\begin{abstract}
This study aims to determine the factors that affect SEBI student interest subject to Islamic Accounting Public Accounting profession. These are intrinsic work values , socio-economic and personality factors. The findings showed that the number of Islamic Accounting students are not interested in the profession of public accounting is far greater than the number of students interested in the public accounting profession, which is 22: 60 . This research note that, although more than $50 \%$ students of Islamic Accounting class of 2008 and 2009 have a grasp of the Public Accounting profession, but the whole or $100 \%$ of these students have never had an internship experience in Public Accounting Firm (KAP). The study found the three factors of intrinsic work factors, socio-economic and personality are not significantly affect the interest of students towards public accounting profession.
\end{abstract}

Kata kunci: the interest, the student, Islamic accounting, public accounting profession.

\section{PENDAHULUAN}

Indonesia saat ini masih kekurangan jumlah Akuntan Publik. Berdasarkan data dari Institut Akuntan Publik Indonesia (IAPI), jumlah Akuntan Publik di Indonesia hingga 31 Maret 2011 baru 926 orang dari total penduduk 237 juta jiwa. Padahal, Ketua Umum IAPI, Tia Adityasih kepada Pikiran Rakyat Online (5 April 2011) menyebutkan data dari Direktorat Jenderal Pajak, Kementerian Keuangan tahun 2010 bahwa dari 1,8 juta wajib pajak badan yang ada (baik berupa PT, CV, Koperasi, Perhimpunan dan lain-lain) terdapat sekitar 400.000 perusahaan yang memiliki omset Rp 50.000.000.000. Berdasarkan Undangundang Perseroan Terbatas (PT), perusahaan dengan omset minimal Rp 50.000.000.000 wajib diaudit. Oleh karena itu, jika setiap satu Akuntan Publik melakukan audit sebanyak 40 wajib pajak badan, maka Indonesia memerlukan sekitar 10.000 Akuntan Publik.

Data jumlah Akuntan Publik dari Pusat Pembinaan Akuntan dan Jasa Penilai (PPAJP), Badan Pusat Statistik (BPS) serta IAPI menunjukkan bahwa, pada tahun 2010 jumlah Akuntan Publik di Indonesia masih sangat rendah dibandingkan beberapa Negara ASEAN (Association of South-East Asian Nations) yakni 905 Akuntan Publik dari 234.000.000 penduduk. Sedangkan 
Singapura dengan jumlah penduduk 5 juta jiwa memiliki 15.120 Akuntan Publik, Filipina dengan jumlah penduduk sekitar 88.000 .000 jiwa memiliki 15.020 orang Akuntan Publik, Thailand dengan penduduk sekitar 66.000.000 jiwa memiliki 6.070 Akuntan Publik, Malaysia dengan jumlah penduduk sekitar 25.000.000 jiwa memiliki 2.460 Akuntan Publik dan Vietnam dengan jumlah penduduk sekitar 85.000.000 jiwa memiliki 1.500 Akuntan Publik.

Masih berdasarkan sumber data diatas, dari 905 Akuntan Publik di Indonesia tersebut $64 \%$ telah berusia di atas 51 tahun, 25\% berumur $41-50$ tahun, dan hanya $11 \%$ yang berusia muda yakni 26-40 tahun. Hal tersebut sesuai dengan pernyataan Tya Adityasih (Pikiran Rakyat, 5 April 2011) bahwa sejak 1997 hingga kini, pertumbuhan jumlah Akuntan Publik Indonesia tidak signifikan dan cenderung stagnan. Padahal, menurut Tarkosunaryo (2010), jumlah sarjana akuntansi di Indonesia setiap tahunnya berjumlah ratusan ribu.

Secara umum mahasiswa sarjana akuntansi yang telah menyelesaikan jenjang pendidikan S1 memiliki alternatif pilihan karir. Pertama,mereka dapat langsung bekerja sebagai karyawan di perusahaan, instansi pemerintah maupun berwirausaha. Kedua,melanjutkan pendidikan S2. Ketiga,melanjutkan pendidikan profesi untuk menjadi Akuntan Publik (Zulpahmi dkk., 2010). Pilihan karir diatas berlaku untuk semua sarjana akuntansi termasuk di dalamnya sarjana Akuntansi Syariah.

Di Indonesia, sampai dengan Januari 2012 sudah terdapat dua Sekolah Tinggi Ekonomi Islam (STEI) yang membuka program studi Akuntansi Syariah yakni STEI SEBI Depok dan STEI TAZKIA Bogor (Amelia, 2010). Mahasiswa Akuntansi Syariah secara kompetensi tidak hanya dibekali ilmu akuntansi saja. Seperti yang tertuang dalam Buku Panduan Akademik STEI SEBI, terdapat beberapa mata kuliah yang termasuk dalam rumpun syariah dan menjadi keunggulan tersendiri bagi mahasiswa Akuntansi Syariah, diantaranya Fiqh Muamalah, Fiqh Transaksi Keuangan Kontemporer serta Fiqh Riba Gharar. Sehingga dalam berkarir kedepannya, sarjana Akuntansi Syariah diharapkan mampu bekerja lebih profesional dengan tetap berpedoman pada nilai-nilai keislaman yang dimilikinya.

Terkait dengan kondisi rendahnya minat generasi muda akuntansi terhadap profesi Akuntan Publik, dalam penelitian ini hal tersebut dapat dibuktikan dengan data profesi alumni dari Bagian Kemahasiswaan STEI SEBI. Dari data tersebut dapat diketahui bahwa dari 150 sarjana Akuntansi Syariah yakni dari angkatan awal tahun 2001 sampai dengan angkatan 2007, hanya 5 orang yang berprofesi menjadi Akuntan Publik ${ }^{1}$ atau hanya 0,033\%.

Melihat rendahnya jumlah mahasiswa yang berprofesi sebagai Akuntan Publik tersebut, maka dilakukan penelitian mengenai tingkat minat mahasiswa STEI SEBI jurusan Akuntansi Syariah terhadap profesi Akuntan Publik serta menganalisis faktor-faktor yang mempengaruhi minat profesi Akuntan Publik. Selain itu, penelitian ini termotivasi oleh penelitian-penelitian terdahulu mengenai minat mahasiswa terhadap profesi akuntan.

Sebelumnya, Zulpahmi dkk. (2010) meneliti tentang analisis faktor-faktor pemilihan karir akuntan bagi mahasiswa akuntansi dan menetapkan bahwa 
terdapat enam faktor yaitu faktor intrinsik, penghasilan, pertimbangan pasar kerja, latar belakang pendidikan SMU, kelebihan dan kelemahan profesi akuntan, serta personalitas. Lisnasari \& Fitriany (2008) meneliti tentang faktor-faktor yang mempengaruhi minat mahasiswa akuntansi untuk mengikuti pendidikan profesi akuntansi (PPAk) (studi empiris di Universitas Indonesia). Faktor-faktor tersebut adalah motivasi kualitas, motivasi karier, motivasi ekonomi, motivasi gelar, motivasi mengikuti Ujian Sertifikasi Akuntan Publik (USAP), biaya pendidikan, serta lama pendidikan PPAk.

Selain penelitian terdahulu diatas, Suhartono \& B. Agung Hartono (2002: 167-168) dalam bukunya Perkembangan Peserta Didik menyebutkan faktor-faktor yang mempengaruhi minat yaitu faktor sosial-ekonomi, tempat tinggal dan faktor lingkungan. Sedangkan Yuwono (2001, hlm. 40) menyebutkan faktor-faktor utama yang mempengaruhi minat seseorang terhadap suatu pekerjaan yakni kondisi pekerjaan, sistem pendukung serta pribadi pekerja.

Dalam penelitian ini dilakukan penggabungan faktor-faktor diatas untuk kemudian menetapkan beberapa faktor yang akan digunakan dalam penelitian. Faktor pertimbangan pasar kerja, motivasi kualitas serta motivasi karier digabungkan kedalam faktor intrinsik pekerjaan. Faktor penghasilan, sistem pendukung, motivasi ekonomi, tempat tinggal dan lingkungan digabung kedalam faktor sosial-ekonomi. Faktor kelebihan dan kelemahan profesi akuntan dan pribadi pekerja digabung kedalam faktor personalitas. Sedangkan faktor latar belakang pendidikan SMU dimasukkan kedalam data demografi responden. Faktor motivasi gelar, motivasi mengikuti Ujian Sertifikasi Akuntan Publik (USAP), biaya pendidikan, serta lama pendidikan PPAk tidak digunakan karena dianggap kurang relevan dengan variabel minat terhadap profesi Akuntan Publik. Sehingga dalam penelitian ini ditetapkan tiga faktor yang mempengaruhi minat profesi Akuntan Publik, yaitu faktor nilai intrinsik pekerjaan, faktor sosialekonomi dan faktor personalitas.

\section{TELAAH LITERATUR}

\subsection{TEORI MINAT}

John Holland dalam Efriyani Djuwita (2003) menjelaskan minat sebagai aktivitas atau tugas-tugas yang membangkitkan perasaan ingin tahu, perhatian dan memberi kesenangan atau kenikmatan. Minat dapat menjadi indikator dari kekuatan seseorang yang akan membuat dirinya termotivasi untuk mempelajari sesuatu hal dan menunjukkan kinerja yang tinggi. Masih menurut Holland, bakat atau kemampuan seseorang akan sulit berkembang dengan baik apabila tidak diawali dengan adanya minat pada bidang yang akan ditekuni.

Minat, sebagaimana yang dijelaskan Hurlock dalam bukunya Psikologi Perkembangan (1980), tidak muncul begitu saja dalam diri seseorang. Minat terbentuk melalui pertumbuhan, kematangan berfikir, proses belajar dan pengalaman. Minat dapat berubah sesuai dengan fase perkembangan dan 
pertumbuhan seseorang. Semakin dewasa seseorang maka semakin stabil kondisi minat dalam dirinya baik secara kuantitatif maupun kualitatif.

Berikut beberapa kondisi yang mempengaruhi minat individu menurut Suhartono \& B. Agung Hartono (2002, hlm. 167-168) yaitu:

\section{Faktor sosial-ekonomi}

Kondisi sosial-ekonomi keluarga banyak menentukan kehidupan pendidikan dan karir anak. Kondisi sosial yang menggambarkan status orang tua merupakan faktor yang 'dilihat' oleh anak untuk menentukan pilihan sekolah dan pekerjaan. Secara tidak langsung keberhasilan orang tuanya merupakan ‘beban' bagi anak, sehingga dalam menentukan pilihan pendidikan tersirat untuk ikut mempertahankan kedudukan orang tuanya.

\section{Tempat tinggal}

Dimana orang tinggal banyak dipengaruhi oleh keinginan yang biasa mereka penuhi pada kehidupan sebelumnya, apakah kebiasaan tersebut masih dapat dilakukan atau tidak.

\section{Faktor Lingkungan}

Yang dimaksud lingkungan disini meliputi 3 macam. Pertama, lingkungan kehidupan masyarakat, seperti lingkungan masyarakat perindustrian, pertanian lingkungan perdagangan, lingkungan masyarakat akademik atau lingkungan yang anggota masyarakat pada umumnya terpelajar atau terdidik. Lingkungan kehidupan semacam itu akan membentuk sikap anak dalam menentukan pola kehidupan, yang pada gilirannya akan mempengaruhi pemikirannya dalam menentukan jenis pendidikan dan pekerjaan yang diidamkannya.

Kedua, lingkungan kehidupan rumah tangga dan kondisi sekolah. Lembaga pendidikan atau sekolah yang baik mutunya, yang memelihara kedisiplinan tinggi, akan sangat berpengaruh terhadap pembentukan sikap dan perilaku kehidupan pendidikan anak dan pola pikirnya dalam menghadapi karir.

Ketiga, lingkungan kehidupan teman sebaya. Pergaulan teman sebaya akan memberikan pengaruh terhadap kehidupan pendidikan masing-masing remaja.

Sedangkan menurut Yuwono (2001, hlm. 40) dalam arihdyacaesar.wordpress.com, faktor - faktor utama yang mempengaruhi minat seseorang terhadap suatu pekerjaan yaitu:

1. Kondisi pekerjaan

Tempat kerja yang memiliki suasana yang menyenangkan dengan didukung oleh kerja sama yang profesional dan saling bantu dapat meningkatkan produktivitas.

\section{Sistem pendukung}

Dalam bekerja sangat diperlukan sistem pendukung yang memadai bagi para pekerjanya sehingga diperoleh hasil produksi yang maksimal, misalnya fasilitas 
kendaraan, perlengkapan pekerjaan yang memadai, kesempatan promosi, kenaikan pangkat/kedudukan.

\section{Pribadi pekerja}

Pribadi pekerja meliputi semangat kerja, pandangan pekerja terhadap pekerjaannya, kebanggan memakai atribut bekerja, sikap terhadap pekerjaannya.

Dariyo (2003, hlm. 72-75) dalam bukunya Psikologi Perkembangan Dewasa Muda menjelaskan adanya keterkaitan antara kepribadian dan karir seseorang. Menurut Dariyo, kepribadian merupakan disposisi psiko-fisiologis yang mengarahkan dan mengontrol perilaku seseorang dalam memilih suatu bidang karir tertentu. Setiap perasaan, pemikiran ataupun perilaku nyata dipengaruhi oleh karakteristik kepribadian. Oleh sebab itu, dalam pemilihan jurusan, minat-bakat, keterampilan ataupun profesi dipengaruhi oleh kepribadian.

\subsection{PROFESI AKUNTANSI DALAM PERSPEKTIF SYARI'AH}

Profesi Akuntan Publik merupakan salah satu dari berbagai jenis profesi akuntansi. Profesi Akuntan Publik sangat erat kaitannya dengan fungsi auditing oleh pihak eksternal (independen). Menurut Harahap (2002), fungsi auditing dalam perspektif syari'ah sesuai dengan makna yang terkandung dalam surat Al-Baqarah ayat 282 yang artinya:

"Wahai orang-orang yang beriman! Apabila kamu melakukan utang-piutang untuk waktu yang ditentukan, hendaklah kamu menuliskannya. Dan hendaklah seorang penulis di antara kamu menuliskannya dengan benar. Janganlah penulis menolak untuk menuliskannya sebagaimana Allah telah mengajarkan kepadanya, maka hendaklah dia menuliskan. Dan hendaklah orang yang berutang itu mendiktekan, dan hendaklah dia bertakwa kepada Allah, Tuhannya, dan janganlah dia mengurangi sedikit pun daripadanya. Jika yang berutang itu orang yang kurang akalnya atau lemah (keadaannya), atau tidak mampu mendiktekan sendiri, maka hendaklah walinya mendiktekannya dengan benar. Dan persaksikanlah dengan dua orang saksi laki-laki di antara kamu. Jika tidak ada (saksi) dua orang laki-laki, maka (boleh) seorang laki-laki dan dua orang perempuan di antara orang-orang yang kamu sukai dari para saksi (yang ada), agar jika yang seorang lupa maka yang seorang lagi mengingatkannya. Dan janganlah saksi-saksi itu menolak apabila dipanggil. Dan janganlah kamu bosan menuliskannya, untuk batas waktunya baik (utang itu) kecil maupun besar. Yang demikian itu, lebih adil di sisi Allah, lebih dapat menguatkan kesaksian, dan lebih mendekatkan kamu kepada ketidakraguan, kecuali jika hal itu merupakan perdagangan tunai yang kamu jalankan diantara kamu, maka tidak ada dosa bagi kamu jika kamu tidak menuliskannya. Dan ambillah saksi apabila kamu berjual beli, dan janganlah penulis dipersulit dan begitu juga saksi. Jika kamu lakukan (yang demikian), maka sungguh, hal itu suatu kefasikan pada kamu. Dan bertakwalah kepada Allah, Allah memberikan pengajaran kepadamu, dan Allah Maha Mengetahui segala 
sesuatu.” (Q.S. Al-Baqarah: 282).

Makna dari surat Al-Baqarah ayat 282 diatas lebih menekankan pada kewajiban menulis (fungsi akuntansi). Namun dari segi substansi dapat disimpulkan bahwa Syari'at Islam sangat mengedepankan aspek kebenaran pencatatan, kejujuran, kebenaran informasi serta keadilan dalam bermuamalah. Pada dasarnya ayat diatas menggambarkan bahwa fungsi pencatatan saja tidak cukup, tetapi perlu adanya persaksian dari pihak lain. Fungsi saksi dalam konteks ini diperlukan jika pelaku muamalah adalah seorang yang lemah akal dan tidak mampu menulis, maka diminta orang lain melakukan kewajiban tersebut disertai dengan saksi.

Fungsi auditing sebenarnya sama dengan fungsi persaksian dalam ayat diatas. Profesi akuntan yang memiliki tugas relevan dengan fungsi kesaksian (attestation) disebut sebagai auditor. Seorang auditor adalah seseorang yang menjalankan fungsinya sebagai saksi dan menyaksikan apakah informasi yang disajikan oleh pelaku muamalah disajikan secara wajar atau tidak. Sehingga keberadaan seorang auditor tentu sangat mendukung bagi pelaksanaan Syari'at Islam dalam dunia akuntansi saat ini. (Harahap, 2002)

\subsection{PROFESI AKUNTAN PUBLIK}

Definisi Akuntan Publik dalam Keputusan Menteri Keuangan Republik Indonesia No.423/KMK.06/2002 BAB I Ketentuan Umum Pasal 1 ayat 2 adalah Akuntan yang telah memperoleh ijin dari Menteri untuk memberikan jasa sebagaimana diatur dalam Keputusan Menteri Keuangan.

Akuntan Publik atau kadang disebut sebagai Akuntan ekstern (external accountant), menurut Soemarso (1999), adalah Akuntan independen yang memberikan jasa-jasanya atas dasar pembayaran tertentu. Mereka bekerja secara bebas, pada umumnya mendirikan suatu kantor akuntan. Termasuk dalam kategori Akuntan Publik adalah akuntan yang bekerja pada kantor akuntan tersebut. Untuk dapat berpraktek sebagai Akuntan Publik dan mendirikan kantor akuntan, seseorang harus memperoleh izin dari Depertemen Keuangan.

Dari definisi-definisi di atas, dapat disimpulkan bahwa Akuntan Publik adalah Akuntan independen yang menjalankan praktik akuntansi untuk kepentingan umum, memberikan jasa-jasanya atas dasar pembayaran tertentu dan bekerja pada suatu kantor akuntan. Seorang Akuntan Publik yang ingin mendirikan kantor akuntan harus mendapatkan izin dari Departemen Keuangan.

Untuk dapat masuk ke dalam organisasi profesi dan menjalankan profesinya, biasanya seseorang harus menjalani pendidikan dan latihan khusus dan lulus ujian profesi. Pembahasan profesi akuntansi tidak dapat dilepaskan dari sistem pendidikan akuntansi (Suwardjono, 2002). Khomsiyah (2010) menjelaskan mengenai proses pendidikan profesi Akuntan Publik seperti yang dijelaskan dalam www.iapi.or.id dan www iaiglobal.or.id, bahwa untuk mendapatkan izin sebagai Akuntan Publik diperlukan proses yang cukup panjang. Berawal dari pendidikan S1 Akuntansi, kemudian Pendidikan Profesi Akuntansi, mengikuti ujian sertifikasi atau ujian Indonesia CPA dan mengajukan izin ke Kementerian Keuangan. 
Seseorang yang sudah memiliki gelar Akuntan memiliki kesempatan untuk mengikuti Indonesia CPA Examination (Certified Public Accountant). Setelah lulus dari ujian tersebut maka seorang Akuntan bisa mendapatkan gelar Indonesia CPA. Untuk bisa mengajukan izin menjadi seorang Akuntan Publik, maka seorang Indonesia CPA harus memenuhi persyaratan sebagaimana yang tercantum dalam Pasal 5 Peraturan Menteri Keuangan No:17/PMK.01/2008.

Lulusan akuntansi banyak berhadapan dengan pilihan karir. Termasuk pilihan profesi Akuntan Publik. Untuk menuju profesi tersebut tidaklah mudah dan proses yang harus dilalui cukup panjang. Selain harus menguasai berbagai mata ujian yang akan diujikan, biaya yang harus dikeluarkan untuk mengikuti ujian profesi tersebut menjadi pertimbangan tersendiri. Kemungkinan hal-hal diatas menjadi alasan yang tepat untuk menjelaskan fenomena kenapa jumlah Akuntan Publik di Indonesia masih sangat sedikit.

\subsection{PENELITIAN TERDAHULU}

Pertama, penelitian Zulpahmi dkk. (2010) dengan judul analisis faktor-faktor pemilihan karir akuntan bagi mahasiswa akuntansi. Penelitiann dilakukan dengan menggunakan analisis chi kuadrat untuk mengetahui diterima atau ditolaknya faktor-faktor yang selalu dipertimbangkan oleh mahasiswa akuntansi dalam pemilihan karir akuntan. Hipotesis yang penulis tetapkan sebelumnya adalah bahwa terdapat enam faktor yaitu: intrinsik, penghasilan, pertimbangan pasar kerja, latar belakang pendidikan SMU, kelebihan dan kelemahan profesi akuntan, serta personalitas merupakan faktor-faktor yang dipertimbangkan oleh mahasiswa dalam pemilihan karir akuntan.

Berdasarkan hasil pembahasan dalam penelitian tersebut dapat diketahui bahwa hipotesa atas ke enam faktor diatas yang diterima sebagai faktor yang selalu dipertimbangkan oleh mahasiswa ada lima faktor, yaitu faktor intrinsik, penghasilan, pertimbangan pasar kerja, kelebihan dan kelemahan profesi akuntan serta personalitas dengan faktor intrinsik sebagai faktor yang paling dominan.

Kedua, Lisnasari \& Fitriany (2008) meneliti tentang faktor-faktor yang mempengaruhi minat mahasiswa akuntansi untuk mengikuti pendidikan profesi akuntansi (PPAk) (studi empiris di Universitas Indonesia). Faktor-faktor tersebut adalah motivasi kualitas, motivasi karier, motivasi ekonomi, motivasi gelar, motivasi mengikuti Ujian Sertifikasi Akuntan Publik (USAP), biaya pendidikan, serta lama pendidikan PPAk. Pengolahan data penelitian tersebut menggunakan analisis regresi linier berganda. Hasil penelitian menunjukkan bahwa secara keseluruhan, motivasi karir dan motivasi mengikuti USAP merupakan faktor yang secara signifikan mempengaruhi minat mahasiswa untuk mengikuti PPAk. Hal ini bisa jadi karena gelar akuntan yang diperoleh dari PPAk merupakan syarat utama untuk dapat mengikuti USAP. Sertifikasi yang diperoleh tersebut merupakan syarat penting untuk dapat meniti karir di bidang Akuntan Publik.

Jika melihat faktor-faktor yang mempengaruhi minat mahasiswa mengikuti PPAk pada masing-masing program studi, terdapat perbedaan faktor yang mempengaruhi. Pada mahasiswa S1 akuntansi reguler, tidak ada satu pun faktor mempengaruhi minat mahasiswa untuk mengikuti PPAk. Pada mahasiswa S1 
ekstensi, faktor-faktor yang mempengaruhi minat mahasiswa mengikuti PPAk yaitu motivasi karier, motivasi gelar, dan lama pendidikan PPAk. Pada mahasiswa PPAk, faktor-faktor yang mempengaruhi minat mahasiswa mengikuti PPAk yaitu motivasi karier dan motivasi mengikuti USAP.

\subsection{KERANGKA TEORI}

Dalam penelitian ini, faktor-faktor yang ditetapkan sebagai variabel independen (X) merupakan penggabungan faktor-faktor yang terdapat dalam penelitian terdahulu diatas serta teori minat pada pembahasan awal. Dalam penelitian ini digabungkan faktor-faktor diatas untuk kemudian ditetapkan tiga faktor yang akan digunakan dalam penelitian. Penggabungan faktor-faktor tersebut disajikan dalam tabel berikut:

Tabel 1. Penggabungan Faktor Pembentuk Variabel Independen

\begin{tabular}{|c|c|c|}
\hline Faktor & Sumber & $\begin{array}{l}\text { Variabel } \\
\text { Independen (X) }\end{array}$ \\
\hline Kondisi pekerjaan & $\begin{array}{l}\text { Suhartono \& B. Agung Hartono } \\
\text { (2002) }\end{array}$ & \multirow{4}{*}{$\begin{array}{l}\text { Nilai intrinsik } \\
\text { Pekerjaan (X1) }\end{array}$} \\
\hline Pertimbangan pasar kerja & Zulpahmi dkk. (2010) & \\
\hline Motivasi kualitas & Lisnasari\&Fitriany (2008) & \\
\hline Motivasi karier & Lisnasari\&Fitriany (2008) & \\
\hline Penghasilan & Zulpahmi dkk. (2010) & \multirow{4}{*}{$\begin{array}{l}\text { Sosial-ekonomi } \\
\text { (X2) }\end{array}$} \\
\hline Sistem pendukung & Yuwono (2001) & \\
\hline Motivasi ekonomi & Lisnasari\&Fitriany (2008) & \\
\hline $\begin{array}{l}\text { Tempat tinggal dan } \\
\text { lingkungan }\end{array}$ & $\begin{array}{l}\text { Suhartono \& B. Agung Hartono } \\
\text { (2002) }\end{array}$ & \\
\hline $\begin{array}{l}\text { Kelebihan dan kelemahan } \\
\text { profesi akuntan }\end{array}$ & Zulpahmi dkk. (2010) & \multirow{2}{*}{ Personalitas (X3) } \\
\hline Pribadi pekerja & Yuwono (2001) & \\
\hline
\end{tabular}

Dari tabel 2.1 diatas dapat disimpulkan bahwa faktor-faktor yang mempengaruhi terhadap minat mahasiswa Akuntansi Syariah terhadap profesi Akuntan Publik adalah faktor nilai intrinsik pekerjaan, sosial-ekonomi dan personalitas. Hubungan pengaruh tersebut digambarkan sebagai berikut:

\section{METODE PENELITIAN}

\subsection{PEMILIHAN RESPONDEN}

Untuk memenuhi tujuan penelitian, responden yang dipilih adalah mahasiswa STEI SEBI jurusan Akuntansi Syariah angkatan 2008 dengan jumlah 47 orang (22 laki-laki, 25 perempuan) dan angkatan 2009 dengan jumlah 48 orang (16 lakilaki, 32 perempuan), sehingga jumlah keseluruhan 95 orang responden.

\subsection{PENGUMPULAN DAN PENGOLAHAN DATA}

Data yang digunakan dalam penelitian diperoleh dari Bagian Kemahasiswaan STEI SEBI terkait jumlah alumni mahasiswa STEI SEBI (2001-2007 beserta profesi dari setiap alumnus serta referensi buku, jurnal artikel, majalah, internet, maupun referensi lainnya. Selain itu data jumlah mahasiswa STEI SEBI jurusan Akuntansi 
Syariah Angkatan 2008 dan 2009 juga diperoleh melalui observasi langsung di STEI SEBI atau menggunakan kuesioner.

Prosedur pengolahan data yang akan dilakukan adalah sebagai berikut:

\section{Uji Validitas dan Reliabilitas Kuesioner}

Validitas adalah tingkat keandalan dan kebenaran alat ukur yang digunakan. Instrumen yang valid merupakan instrumen yang benar-benar tepat untuk mengukur apa yang hendak di ukur. Uji reliabilitas berguna untuk menetapkan apakah instrumen atau kuesioner dapat digunakan lebih dari satu kali, setidaknya oleh responden yang sama, akan menghasilkan data yang konsisten. Reliabilitas instrumen menunjukkan tingkat konsistensi.

Pengukuran validitas dan reliabilitas mutlak dilakukan, karena jika instrumen yang digunakan sudah tidak valid dan reliabel maka dipastikan hasil penelitiannya pun tidak akan valid dan reliabel (Sugiyono, 2007).

\section{Statistik Deskriptif}

Statistik deskriptif merupakan proses transformasi data penelitian dalam bentuk tabulasi sehingga mudah dipahami dan diinterpretasikan. Dalam penelitian ini, statistik deskriptif dilakukan secara manual dan dimaksudkan untuk menggambarkan dan menyajikan secara ringkas sejumlah besar terkait data demografi responden, yaitu jenis kelamin, pendidikan pra kuliah, perolehan beasiswa kuliah, Indeks Prestasi Kumulatif (IPK), pekerjaan orangtua, pemahaman profesi dan pengalaman magang.

\section{Uji Hipotesis}

Pengujian hipotesis dilakukan dengan menggunakan analisis regresi logistik untuk mengetahui pola hubungan antara variabel independen terhadap variabel dependennya. Analisis regresi logistik merupakan salah satu metode regresi yang digunakan untuk mencari hubungan antara variabel dependen $(\mathrm{Y})$ dengan satu atau lebih variabel independen (X). Regresi logistik ini hanya digunakan untuk kasus khusus, yaitu variabel dependen (Y) adalah variabel kualitatif yang biner atau dikotom.

Dalam penelitian ini hanya terdapat dua kemungkinan dari nilai Y, yaitu berminat $(\mathrm{Y}=1)$ atau tidak berminat $(\mathrm{Y}=0)$. Model Dari Analisis Regresi Logistik adalah sebagai berikut:

$$
\log (P / 1-p)=a+b_{1} X_{1}+b_{2} X_{2}+b_{3} X_{3}
$$

Keterangan:

$\mathrm{P}$; adalah probabilitas $\mathrm{Y}=1$

a; konstanta

b; koefisien regresi

$\mathrm{X}_{1}$; faktor nilai intrinsik pekerjaan

$\mathrm{X}_{2}$; faktor sosial ekonomi

$\mathrm{X}_{3}$; faktor personalitas 
3.3 PROFIL MAHASISWA STEI SEBI JURUSAN AKUNTANSI SYARIAH

Berdasarkan data dari Bagian Akademik STEI SEBI, selama 7 tahun terakhir yakni sejak tahun 2004 sampai dengan tahun 2010 jumlah mahasiswa Akuntansi Syari'ah STEI SEBI mengalami peningkatan yang signifikan. Tahun 2004 jumlah mahasiswa STEI SEBI jurusan Akuntansi Syariah hanya berjumlah 14 orang. Tahun 2005 meningkat menjadi 27 orang, tahun 2006 berjumlah 34 orang, tahun 2007 berjumlah 40 orang, tahun 2008 berjumlah 47 orang, tahun 2009 berjumlah 50 orang dan tahun 2010 berjumlah 62 orang.

Jumlah mahasiswa Akuntansi Syariah pada tahun 2004 sampai dengan 2007 merupakan gabungan jumlah mahasiswa Akuntansi Syariah dan Akuntansi Manajemen Zakat. Untuk mahasiswa angkatan tahun 2011 belum dilakukan penjurusan tetap sehingga tidak dilakukan pendataan.

Dalam hal kompetensi, sarjana Akuntansi Syariah diharapkan memiliki penguasaan wawasan yang baik atas dasar-dasar ilmu-ilmu Islam (Islamic studies) sehingga menghasilkan Islamic personal integrity yang kuat, memiliki ketrampilan dan keahlian dalam melakukan pencatatan akad-akad transaksi muamalah, mampu menyusun dan menganalisis laporan keuangan, serta mengaudit perusahaan atau lembaga, baik yang beroperasi secara konvensional maupun yang sesuai dengan prinsip-prinsip syari'ah Islam, memiliki personal dan interpersonal skills yang baik, serta memilki kapasitas yang tinggi dalam belajar.

Untuk karir prospektif, sarjana akuntansi syariah STEI SEBI dapat berkarir sebagai akuntan di perusahaan baik lembaga keuangan syariah maupun perusahaan jasa, perdagangan dan manufaktur, menjadi auditor internal maupun eksternal, internal syariah review, manajer keuangan, konsultan atau analis di sektor Islamic finance dan financial institution, akademisi dan peneliti dibidang Islamic accounting atau menjadi wirausahawan yang berwawasan ekonomi syariah.

\section{HASIL DAN ANALISIS}

\subsection{KARAKTERISTIK RESPONDEN}

Karakteristik keseluruhan responden dalam penelitian ini disajikan dalam tabel data demografi responden berikut:

Tabel 2. Data Demografi Responden

\begin{tabular}{|c|c|c|c|c|c|}
\hline & $\mathbf{n}$ & $\%$ & & $\mathbf{n}$ & $\%$ \\
\hline Angkatan & & & $\begin{array}{l}\text { Minat pada jurusan } \\
\text { Akuntansi Syariah (AS) }\end{array}$ & & \\
\hline 2008 & 46 & 56 & Berminat dari awal: & & \\
\hline 2009 & 36 & 44 & $\begin{array}{lll}\begin{array}{l}\text { Prospek karir di bidang } \\
\text { akuntansi }\end{array} & & \\
\end{array}$ & 18 & 22 \\
\hline Total & 82 & 100 & $\begin{array}{l}\text { Sesuai dengan kemampuan } \\
\text { logis-matematis }\end{array}$ & 12 & 15 \\
\hline Jenis Kelamin & & & $\begin{array}{l}\text { Mengikuti saran } \\
\text { orangtua/saudara/teman }\end{array}$ & 15 & 18 \\
\hline Laki-laki & 30 & 37 & Lain-lain & 3 & 4 \\
\hline Perempuan & 52 & 63 & Tidak berminat dari awal: & & \\
\hline Total & 82 & 100 & $\begin{array}{l}\text { Terprovokasi } \\
\text { orangtua/saudara/teman }\end{array}$ & 10 & 12 \\
\hline
\end{tabular}




\begin{tabular}{|c|c|c|c|c|c|}
\hline Pendidikan pra kuliah & & & Akuntansi mendekati IPA & 9 & 11 \\
\hline SLTA-IPS & 21 & 26 & Coba-coba & 9 & 11 \\
\hline SLTA-IPA & 32 & 39 & Lain-lain & 6 & 7 \\
\hline SMK-Akuntansi & 14 & 17 & Total & 82 & 100 \\
\hline Lain-lain & 15 & 18 & Pekerjaan Orangtua & & \\
\hline Total & 82 & 100 & PNS & 15 & 18 \\
\hline $\begin{array}{ll}\text { Beasiswa } & \text { SDM } \\
\text { EKSPAD } & \\
\end{array}$ & & & Profesional & 0 & 0 \\
\hline Ya & 40 & 49 & Swasta & 10 & 12 \\
\hline Tidak & 42 & 51 & Wiraswasta & 43 & 53 \\
\hline Total & 82 & 100 & Lainnya & 14 & 17 \\
\hline IPK mutakhir & & & Total & 82 & 100 \\
\hline $2,00-2,49$ & 0 & 0 & $\begin{array}{l}\text { Memahami profesi } \\
\text { Akuntan publik (AP) }\end{array}$ & & \\
\hline $2,50-2,99$ & 11 & 13 & Ya & 61 & 74 \\
\hline $3,00-3,49$ & 41 & 50 & Belum & 21 & 26 \\
\hline $3,50-4,00$ & 27 & 33 & Total & 82 & 100 \\
\hline Tidak menjawab & 3 & 4 & Magang di KAP & & \\
\hline Total & 82 & 100 & Belum pernah & 82 & 100 \\
\hline & & & Sudah pernah & 0 & 0 \\
\hline & & & Total & 82 & 100 \\
\hline
\end{tabular}

Dalam penelitian ini, tingkat minat mahasiswa terhadap profesi Akuntan Publik diukur melalui satu pertanyaan langsung mengenai level minat responden terhadap profesi Akuntan Publik dengan skala 1 sampai 5. Jawaban level minat mahasiswa tersebut dibagi menjadi 2 (dua) kategori. Pertama, level minat 1 sampai 3 dikategorikan sebagai kategori tidak berminat dan diberi kode 0 (nol) karena level tersebut kurang dari nilai rata-rata minat 3,07 $(<3,07)$. Kedua, level 4 sampai 5 dikategorikan sebagai kategori berminat dan diberi kode 1 (satu) karena level tersebut lebih dari nilai rata-rata minat 3,07 (>3,07). Hasil penelitian mengenai kondisi minat disajikan dalam tabel berikut:

Tabel 3. Minat Mahasiswa terhadap Profesi Akuntan Publik

\begin{tabular}{|l|l|l|l|l|l|}
\hline Berminat & $\mathbf{n}$ & $\mathbf{\%}$ & Tidak Berminat & $\mathbf{n}$ & $\mathbf{\%}$ \\
\hline Level 4 & 17 & 21 & Level 1 & 3 & 4 \\
\hline Level 5 & 5 & 6 & Level 2 & 15 & 18 \\
\hline & & & Level 3 & 42 & 51 \\
\hline Total & 22 & 27 & Total & 60 & 73 \\
\hline Jenis Kelamin & & & Jenis Kelamin & & \\
\hline Laki-laki & 9 & 11 & Laki-laki & 21 & 26 \\
\hline Perempuan & 13 & 16 & Perempuan & 39 & 47 \\
\hline Total & 22 & 27 & Total & 60 & 73 \\
\hline Pendidikan pra kuliah & & & Pendidikan pra kuliah & & \\
\hline SLTA-IPS & 3 & 4 & SLTA-IPS & 18 & 22 \\
\hline SLTA-IPA & 9 & 11 & SLTA-IPA & 23 & 28 \\
\hline SMK-Akuntansi & 5 & 6 & SMK-Akuntansi & 9 & 11 \\
\hline Lain-lain & 5 & 6 & Lain-lain & 10 & 12 \\
\hline Total & 22 & 27 & Total & 60 & 73 \\
\hline Beasiswa SDM EKSPAD & & & Beasiswa SDM EKSPAD & & \\
\hline Ya & 9 & 11 & Ya & 31 & 38 \\
\hline Tidak & 13 & 16 & Tidak & 29 & 35 \\
\hline Total & 22 & 27 & Total & 60 & 73 \\
\hline Minat jurusan AS & & & Minat jurusan AS & & \\
\hline Berminat dari awal & & & Berminat dari awal & & \\
\hline Prospek karir & 7 & 9 & Prospek karir & 11 & 13 \\
\hline Sesuai kemampuan & 4 & 5 & Sesuai kemampuan & 8 & 10 \\
\hline Mengikuti saran & 2 & 2 & Mengikuti saran & 13 & 16 \\
\hline Lain-lain & 0 & 0 & Lain-lain & 3 & 4 \\
\hline & & & & & \\
\hline
\end{tabular}




\begin{tabular}{|l|l|l|l|l|l|}
\hline Tidak berminat dari awal & & & Tidak berminat dari awal & & \\
\hline Terprovokasi teman & 1 & 1,5 & Terprovokasi teman & 9 & 11 \\
\hline Akuntansi mendekati IPA & 5 & 6 & Akuntansi mendekati IPA & 4 & 5 \\
\hline Coba-coba & 1 & 1,5 & Coba-coba & 8 & 9 \\
\hline Lain-lain & 2 & 2 & Lain-lain & 4 & 5 \\
\hline Total & 22 & 27 & Total & 60 & 73 \\
\hline IPK & & & IPK & & \\
\hline $2,00-2,49$ & 0 & 0 & $2,00-2,49$ & 0 & 0 \\
\hline $2,50-2,99$ & 3 & 4 & $2,50-2,99$ & 8 & 10 \\
\hline $3,00-3,49$ & 12 & 15 & $3,00-3,49$ & 29 & 35 \\
\hline $3,50-4,00$ & 7 & 8 & $3,50-4,00$ & 20 & 24 \\
\hline Tidak Menjawab & 0 & 0 & Tidak Menjawab & 3 & 4 \\
\hline Total & 22 & 27 & Total & 60 & 73 \\
\hline Pekerjaan Orangtua & & & Pekerjaan Orangtua & & \\
\hline PNS & 3 & 4 & PNS & 12 & 15 \\
\hline Profesional & 0 & 0 & Profesional & 0 & 0 \\
\hline Swasta & 5 & 6 & Swasta & 7 & 8 \\
\hline Wiraswasta & 12 & 15 & Wiraswasta & 29 & 35 \\
\hline Lainnya & 2 & 2 & Lainnya & 12 & 15 \\
\hline Total & 22 & 27 & Total & 60 & 73 \\
\hline Memahami profesi AP & & & Memahami profesi AP & & \\
\hline Ya & 17 & 21 & Ya & 44 & 54 \\
\hline Belum & 5 & 6 & Belum & 16 & 19 \\
\hline Total & 22 & 27 & Total & 60 & 73 \\
\hline Magang di KAP & & & Magang di KAP & & \\
\hline Belum pernah & 22 & 27 & Belum pernah & 60 & 73 \\
\hline Sudah pernah & 0 & 0 & Sudah pernah & 0 & 0 \\
\hline Total & 22 & 27 & Total & 60 & 73 \\
\hline
\end{tabular}

\subsection{PENGUJIAN HIPOTESIS}

\section{Variabel Intrinsik Pekerjaan}

Variabel intrinsik pekerjaan mempunyai signifikansi 0,958 $(>0,05)$ yang berarti tidak signifikan dan berpengaruh positif karena koefisien (B) dari variabel intrinsik bernilai positif yakni 0,004 . Hasil ini menolak Hipotesis pertama (H1) yang diajukan, yakni variabel intrinsik pekerjaan secara tidak signifikan mempengaruhi minat mahasiswa terhadap profesi Akuntan Publik.

Hasil pengujian tersebut berbeda dengan hasil penelitian yang dilakukan sebelumnya oleh Zulpahmi dkk. (2010) dan Aprilyan (2011) dimana variabel atau faktor intrinsik pekerjaan secara signifikan sangat mempengaruhi minat mahasiswa terhadap profesi akuntan. Hal tersebut dapat disebabkan oleh kurangnya pengetahuan dan pemahaman mahasiswa STEI SEBI jurusan Akuntansi Syariah mengenai profesi Akuntan Publik. Tingkat pemahaman mahasiswa terhadap mata kuliah yang dipelajari, dalam hal ini akuntansi dan auditing, tentunya berkaitan dengan tingkat keseriusan mahasiswa dalam belajar.

Tingkat keseriusan mahasiswa tersebut secara umum dapat diketahui dari latar belakang pendidikan sebelum kuliah dan alasan mahasiswa memilih jurusan Akuntansi Syariah di STEI SEBI. Sebagian besar mahasiswa STEI SEBI jurusan Akuntasi Syariah berasal dari SLTA jurusan IPA dan hanya sedikit yang berasal dari SMK jurusan Akuntansi. Meskipun banyak dari mahasiswa tersebut memilih jurusan Akuntansi Syariah dengan alasan prospek karir di bidang akuntansi (tabel 4.13), namun hal tersebut tidak sejalan dengan minat 
mereka untuk menjadi Akuntan Publik. Kemungkinan besar mahasiswa tersebut sudah memiliki pilihan profesi lain selain Akuntan Publik.

Dari hasil penelitian juga diketahui bahwa seluruh mahasiswa yang menjadi responden dalam penelitian ini menyatakan belum pernah mendapatkan pengalaman magang di Kantor Akuntan Publik, meskipun sebagian besar sudah memahami profesi Akuntan Publik. Sehingga mereka belum mengetahui secara langsung bagaimana praktik nyata pelaksanaan tugas sebagai seorang Akuntan Publik termasuk memahami nilai-nilai intrinsik dari profesi Akuntan Publik. Hal ini tentu menjadi indikator utama rendahnya minat mahasiswa STEI SEBI jurusan Akuntansi Syariah terhadap profesi Akuntan Publik.

Selain itu, jika Yuwono (2001, hlm. 40) menjelaskan bahwa kondisi pekerjaan khususnya tempat kerja yang memiliki suasana menyenangkan dengan didukung oleh kerja sama yang profesional dan saling bantu dapat meningkatkan produktivitas, maka tentu hal tersebut berlaku bagi seseorang yang sudah bekerja. Peningkatan produktivitas terjadi seiring dengan semakin tinggi minat seseorang terhadap pekerjaan yang dijalaninya. Sedangkan dalam penelitian ini responden merupakan mahasiswa yang belum menjadi sarjana dan belum bekerja sehingga belum mengetahui bagaimana kondisi pekerjaan yang akan dijalaninya, terutama pekerjaan sebagai seorang Akuntan Publik.

\section{Variabel Sosial-Ekonomi}

Variabel sosial-ekonomimempunyai signifikansi $0,530(>0,05)$ yang berarti tidak signifikan dan berpengaruh negatif karena koefisien (B) dari variabel intrinsik bernilai negatif yakni -0,061. Hasil ini menolak Hipotesis kedua (H2) yang diajukan, yakni variabel sosial-ekonomi secara tidak signifikan mempengaruhi minat mahasiswa terhadap profesi Akuntan Publik. Hasil pengujian tersebut berbeda dengan teori yang dikemukakan oleh Suhartono \& B. Agung Hartono (2002, hlm. 167-168) dimana variabel atau faktor sosial-ekonomi merupakan faktor yang mempengaruhi minat individu. Hal tersebut dapat disebabkan pengertian minat diatas yang terlalu umum atau tidak bermakna khusus seperti minat dalam memilih pekerjaan sehingga indikator dari faktor sosial-ekonomi tersebut tidak mampu mengukur minat individu dalam memilih profesi Akuntan Publik.

Faktor sosial-ekonomi dalam hal ini mencakup kondisi keluarga, tempat tinggal dan lingkungan sekitar. Lingkungan sekitar mencakup lingkungan masyarakat, lembaga pendidikan sebagai sarana memperoleh ilmu dan lingkungan pergaulan seperti teman sebaya. Dalam konteks kehidupan seseorang maka yang paling mempengaruhi perilaku dan pola pikir adalah lingkungan keluarga. Kaitannya dengan memilih pekerjaan, menurut Suhartono \& B. Agung Hartono (2002, hlm. 167-168), kondisi sosial-ekonomi keluarga banyak menentukan kehidupan pendidikan dan karir seseorang. Kondisi sosial yang menggambarkan status orang tua merupakan faktor yang 'dilihat' oleh anak untuk menentukan pilihan sekolah dan pekerjaan. Secara tidak langsung keberhasilan orang tuanya merupakan 'beban' bagi anak, sehingga dalam menentukan pilihan pendidikan tersirat untuk ikut mempertahankan kedudukan orang tuanya. 
Dari tabel 4.16 diatas diketahui sebagian besar pekerjaan orang tua dari mahasiswa adalah wiraswasta dan sebagian besar pula dari mahasiswa tidak mendapatkan beasiswa kuliah (tabel 4.17). Tabel 4.16 menunjukkan bahwa sebagian besar mahasiswa yang berminat terhadap profesi Akuntan Publik adalah mahasiswa dimana pekerjaan orang tua mahasiswa tersebut adalah wiraswasta. Hal tersebut mengindikasikan bahwa kondisi sosial-ekonomi keluarga tidak selalu mempengaruhi pilihan karir seseorang. Realitanya dalam kehidupan saat ini sudah menjadi hal yang wajar jika orangtua menginginkan kesuksesan yang lebih baik bagi anaknya.

Lingkungan selanjutnya yang paling berpengaruh adalah lembaga pendidikan, dalam hal ini Perguruan Tinggi (PT). Lembaga STEI SEBI sebagai objek menimba ilmu bagi mahasiswa tentunya memiliki peran penting dalam membantu mahasiswa menentukan profesi yang akan dijalaninya selepas menjadi sarjana. Sejauh ini, lembaga STEI SEBI banyak memiliki akses dengan lembaga keuangan syariah di Indonesia sehingga memudahkan mahasiswa mendapatkan informasi mengenai lapangan pekerjaan yang sesuai. Akses lembaga dengan Kantor Akuntan Publik (KAP) dapat dikatakan masih kurang sehingga mahasiswa cenderung sulit mendapatkan informasi mengenai kesempatan magang ataupun bekerja di KAP sebagai auditor junior.

Selain itu, berdasarkan teori yang dikemukakan oleh Hurlock (1980, hlm. 279-280), bahwa jika seseorang memilih suatu pekerjaan atau profesi disebabkan oleh besarnya pengaruh sosial yang ada, bukan berdasarkan minat atau kecenderungan, maka dikhawatirkan justru menimbulkan ketidakpuasan terhadap hasil karyanya, tidak merasa mencintai tugasnya dan akhirnya prestasi kerja sangat menurun.

\section{Variabel Personalitas}

Variabel personalitas mempunyai signifikansi 0,054 $(<0,05)$ yang berarti tidak signifikan dan berpengaruh positif karena koefisien (B) dari variabel intrinsik bernilai positif yakni 0,141. Hasil ini menerima Hipotesis ketiga (H3) yang diajukan, yakni variabel personalitas secara signifikan mempengaruhi minat mahasiswa terhadap profesi Akuntan Publik.

Hasil pengujian tersebut berbeda dengan hasil penelitian Zulpahmi dkk. (2010) dan Aprilyan (2011) dimana faktor personalitas secara signifikan mempengaruhi minat mahasiswa terhadap profesi akuntan. Selain itu, hasil pengujian ini juga berbeda dengan teori yang dikemukakan oleh Yuwono (2001, hlm. 40) bahwa pribadi pekerja merupakan salah satu faktor utama yang mempengaruhi minat seseorang terhadap suatu pekerjaan. Pribadi pekerja meliputi diantaranya semangat kerja, pandangan atau persepsi pekerja terhadap pekerjaannya, kebanggan memakai atribut bekerja serta sikap terhadap pekerjaannya.

Dariyo (2003, hlm. 72-75) dalam bukunya Psikologi Perkembangan Dewasa Muda menjelaskan adanya keterkaitan antara kepribadian dan karir seseorang. Menurutnya, kepribadian merupakan disposisi psiko-fisiologis yang mengarahkan dan mengontrol perilaku seseorang dalam memilih suatu bidang 
karir tertentu. Setiap perasaan, pemikiran ataupun perilaku nyata dipengaruhi oleh karakteristik kepribadian. Oleh sebab itu, dalam pemilihan jurusan, minatbakat, keterampilan ataupun profesi dipengaruhi oleh kepribadian.

Kemampuan atau bakat merupakan salah satu unsur utama dalam kepribadian seseorang. Kemampuan di bidang akuntansi, misalnya, termasuk ke dalam jenis kemampuan kognitif atau kemampuan berfikir logis-matematis. Meskipun setiap orang memiliki kemampuan logis-matematis, namun yang membedakan adalah tingkat dominasi dari kemampuan tersebut. Dalam hasil penelitian ini diketahui tingkat kemampuan mahasiswa yang berminat dan mahasiswa yang tidak berminat terhadap profesi Akuntan Publik cenderung tidak jauh berbeda.

Dari tabel 4.18 diatas diketahui sebagian besar mahasiswa yang berminat dan mahasiswa yang tidak berminat terhadap profesi Akuntan Publik memiliki nilai IPK sama yakni berkisar antara 3,00 sampai 3,49. Begitu juga dengan mahasiswa yang memiliki nilai IPK tinggi antara 3,50 sampai 4,00 sebagian besar justru tidak berminat terhadap profesi Akuntan Publik. Secara teori, seseorang yang memiliki kemampuan tinggi di bidang logis-matematis akan cenderung memilih atau melakukan hal-hal yang menuntut kemampuan berfikir analitis dan cermat, termasuk dalam hal memutuskan untuk mendalami ilmu akuntansi dan memilih profesi yang berkaitan dengan akuntansi seperti halnya profesi Akuntan Publik.

Namun dalam hasil penelitian ini pengaruh dari faktor personalitas tersebut tidak signifikan. Artinya, ketika seorang mahasiswa berminat terhadap profesi Akuntan Publik, maka kontribusi personalitas atau kepribadian mahasiswa terhadap minat sangat kecil atau tidak signifikan. Selain pengukuran personalitas dalam analisis hasil penelitian ini hanya fokus pada kemampuan kognitif, kemungkinan hal lain yang menyebabkan faktor personalitas memiliki pengaruh yang tidak signifikan adalah pemilihan indikator dari personalitas yang kurang tepat sebagai alat ukur dalam instrumen penelitian.

Hasil pengolahan data dengan menggunakan bantuan software SPSS versi 13.0 pada akhirnya menunjukkan bahwa dari ketiga faktor yang ada, diketahui tidak ada satu pun faktor yang secara signifikan mempengaruhi minat mahasiswa terhadap profesi Akuntan Publik. Minat merupakan kecenderungan yang timbul dari dalam diri seseorang, sehingga kemungkinan faktor-faktor yang mempengaruhi minat tersebut sangat banyak baik yang berasal dari eksternal maupun internal diri seseorang.

\section{SIMPULAN}

Berikut kesimpulan dari hasil penelitian:

1. Jumlah mahasiswa STEI SEBI jurusan Akuntansi Syariah angkatan 2008 dan 2009 yang berminat terhadap profesi Akuntan Publik hanya berjumlah 22 orang, sedangkan 60 mahasiswa lainnya tidak berminat terhadap profesi Akuntan Publik. Jumlah mahasiswa keseluruhan 82 orang. 
Dari data demografi responden terlihat bahwa faktor jenis kelamin, latar belakang pendidikan pra kuliah, minat jurusan Akuntansi Syariah serta IPK tidak mempengaruhi minat mahasiswa terhadap profesi Akuntan Publik. Faktor perolehan beasiswa, pekerjaan orangtua, pemahaman terhadap profesi Akuntan Publik serta pengalaman magang berpengaruh terhadap minat mahasiswa terhadap profesi Akuntan Publik.

2. Hasil pengujian hipotesis pertama menunjukkan bahwa faktor intrinsik pekerjaan secara tidak signifikan mempengaruhi minat mahasiswa Akuntansi Syariah terhadap profesi Akuntan Publik. Hasil penelitian tersebut berbeda dengan hasil penelitian yang dilakukan sebelumnya oleh Zulpahmi dkk. (2010) dan Aprylian (2011).

Hasil pengujian hipotesis kedua menunjukkan bahwa faktor sosial-ekonomi secara tidak signifikan mempengaruhi minat mahasiswa Akuntansi Syariah terhadap profesi Akuntan Publik. Hasil penelitian tersebut berbeda dengan teori yang dikemukakan oleh Suhartono \& B. Agung Hartono (2002, hlm. 167-168).

Pengujian hipotesis ketiga menunjukkan bahwa faktor personalitas secara tidak signifikan mempengaruhi minat mahasiswa Akuntansi Syariah terhadap profesi Akuntan Publik. Hasil penelitian tersebut berbeda dengan teori yang dikemukakan oleh Yuwono (2001, hlm. 40) mengenai pengaruh pribadi pekerja terhadap minat seseorang dalam memilih pekerjaan.

Hasil pengolahan data menunjukkan bahwa dari ketiga faktor yang ada, diketahui tidak ada satu pun faktor yang secara signifikan mempengaruhi minat mahasiswa terhadap profesi Akuntan Publik. Minat merupakan kecenderungan yang timbul dari dalam diri seseorang, sehingga kemungkinan faktor-faktor yang mempengaruhi minat tersebut sangat banyak baik yang berasal dari eksternal maupun internal diri seseorang.

\section{DAFTAR PUSTAKA}

Al-Qur’an Al-Karim. Bandung: Syaamil Al-Qur'an.

Dariyo, A. .2003. Psikologi Perkembangan Dewasa Muda. Jakarta: Grasindo.

Djuwita, E. 2003. Memilih dan Mencari Kerja Sesuai dengan Bakat dan Kepribadian. Jakarta: Kawan Pustaka.

Harahap, S.S. 2002. Auditing Dalam Perspektif Islam. Jakarta: Pustaka Quantum.

Hurlock, E. 1980. Psikologi Perkembangan, Suatu Pendekatan Sepanjang Rentang Kehidupan. Jakarta: Erlangga.

Kuncoro, M. 2003. Metode Riset untuk Bisnis \& Ekonomi, Bagaimana Meneliti \& Menulis Tesis?. Jakarta: Erlangga. 
Purwodarminto, W.J.S. 1996. Kamus Umum Bahasa Indonesia. Jakarta: Balai Pustaka.

Reber, A. S. 1985. Dictionary of Psychology. England: Penguin Group.

Santoso, S. 2012. Panduan lengkap SPSS versi 20. Jakarta: Gramedia.

Soemarso. 1999. Akuntansi Suatu Pengantar. $4^{\text {th }}$ ed. Jakarta: Rineka Cipta.

STEI SEBI. 2008. Buku Panduan Akademik STEI SEBI Tahun Akademik 20082009.

Sugiyono. 2007. Metode Penelitian Administrasi. Bandung: Alfabeta.

Sugiyono. 2010. Metode Penelitian Bisnis. Bandung: Alfabeta.

Suharyadi\&Purwanto S.H. 2009. Statistika untuk Ekonomi dan Keuangan Modern. Jakarta: Salemba Empat.

Sunarto\&Hartono B. A. 2002. Perkembangan Peserta Didik. Jakarta: Rineka Cipta.

Suwardjono. 2002. Akuntansi Pengantar. $3^{\text {rd }}$ ed. Yogyakarta: BPFE-Yogyakarta.

Khomsiyah. 2010. Masa Depan Akuntan Publik: Tantangan dan Peluangnya Dalam Pasar Persaingan Global. Diskusi Publik Rancangan Undangundang (UU) Akuntan Publik. Jakarta.

Tarkosunaryo. 2010. Peranan Akuntan Publik dalam Perekonomian Nasional. Diskusi Publik Rancangan Undang-undang (UU) Akuntan Publik. Jakarta.

Amelia, E. 2010. Peta Potensi SDM Ekonomi Islam pada PTAI dan PTU: Analisis Kurikulum, Model Pembelajaran dan Hubungannya dengan Kompetensi SDM pada Industri Keuangan di Indonesia. LEMLIT Universitas Islam Negeri Syarif Hidayatullah, Jakarta.

Lisnasari, Riani Nuraniah dan Fitriany. 2008. Faktor-faktor yang Mempengaruhi Minat Mahasiswa Akuntansi untuk Mengikuti Pendidikan Profesi Akuntansi (PPAk) (Studi Empiris di Universitas Indonesia). The 2nd Accounting Conference, 1st Doctoral Colloquium, and Accounting Workshop, Fakultas Ekonomi Universitas Indonesia, Depok.

Zulpahmi dkk. 2010. Analisis Faktor-faktor Pemilihan Karir Akuntan bagi Mahasiswa Akuntansi. Laporan Penelitian Dosen Fakultas Ekonomi Universitas Muhammadiyah Prof. Dr. Hamka, Jakarta. 
Arihdyacaesar. 2010. Resume Minat (Konsep, Indikator, Pengukuran). Retrieved December 6, 2011 from http://arihdyacaesar.wordpress.com/ 2010/01/13/resume-minat-konsep- indikator-pengukuran/.

Indonesia Kekurangan Akuntan Publik.Retrieved October 17, 2011 from http:/ /www.pikiran-rakyat.com/node/140530.

Institut Akuntan Publik Indonesia (IAPI). 2012. Kode Etik Profesi Akuntan Publik. Retrieved January 26, 2012 from www.iapi.or.id/iapi/artikel/ seputar_iapi/kode_etik_profesi_akuntan_publik.php.

Keputusan Menteri Keuangan Republik Indonesia No.423/KMK.06/2002. (2011). Retrieved December 26, 2011 from ebookbrowse.com/kep-menterikeuangan-no-423-kmk-06-2002-pdf-d74210130.

Peraturan Menteri Keuangan No:17/PMK.01/2008 Tentang Jasa Akuntan Publik. Retrieved December 26, 2011 from www.iapi.or.id/iapi/ pmk_no_17_2008_dan_lampiran.php.

Regresi Logistik. Retrieved February 13, 2012 from http:// www.konsultanstatistik.com/2009/03/regresi-logistik.html.

Undang-Undang No.34 Tahun 1954 Tentang Pemakaian Gelar Akuntan. Retrieved January 14, 2012 from www.sjdih.depkeu.go.id/fullText/1954/ 34TAHUN 1954UU.HTM.

Undang-Undang Republik Indonesia Nomor 5 Tahun 2011 Tentang Akuntan Publik. Retrieved January 14, 2012 from http://www.scribd.com/deleted/ 81899515.

www.iaiglobal.or.id

www.iapi.or.id

\section{(Footnotes)}

${ }^{1}$ Akuntan Publik yang dimaksud adalah akuntan yang belum bersertifikat tetapi aktif sebagai auditor di Kantor Akuntan Publik (KAP). 